\title{
Analysis of triage and care for women victims of road accidents
}

\author{
Análise da triagem e dos atendimentos a mulheres vítimas de acidentes de trânsito \\ Análisis del triagen y de los atendimentos a mujeres víctimas de accidentes de tránsito
}

Fernanda Penido Matozinhos'

ORCID:0000-0003-1368-4248

Ingrid Raiana Silverio'

ORCID: 0000-0003-4974-779X

Juliana Guilherme Boaventura' ORCID:0000-0003-1993-5802

Thaís Moreira Oliveira'

ORCID: 0000-0001-6481-7608

Thales Philipe Rodrigues da Silva'

ORCID:0000-0002-7115-0925

Allana dos Reis Corrêa'

ORCID: 0000-0003-2208-958X

'Universidade Federal de Minas Gerais. Belo Horizonte, Minas Gerais, Brazil.

How to cite this article:

Matozinhos FP, Silverio IR, Boaventura JG, Oliveira TM, Silva TPR, Corrêa AR. Analysis of triage and care for women victims of road accidents. Rev Bras Enferm. 2019;72(4):1013-9. doi: http://dx.doi.org/10.1590/0034-7167-2018-0727

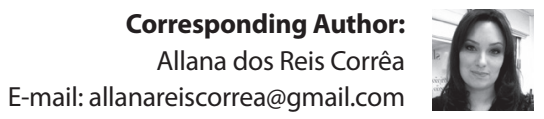

Submission: 09-23-2018

Approval: 11-13-2018

\begin{abstract}
Objective: to analyze the care flow for women victims of Road Traffic Accidents (RTA). Method: a descriptive study with 782 women victims of RAT, classified by the Manchester Triage System (MTS) between 2015 and 2016. The sociodemographic profile and the time between the stages of care were analyzed, as well as care place and outcomes. Results: of the women in the study, $65.47 \%$ were young adults, $80.44 \%$ lived without a partner and $62.28 \%$ lived in the city of Belo Horizonte. Regarding the time between recording and risk classification, the mean was 7.7 minutes (SD: 9.9). The prevalent flowchart was "Great Trauma" (62.92\%). 53.07\% had "Red/Orange" priority level and the most prevalent outcome was "Discharge after consultation/medication". Conclusion: the study shows that the hospital partially fulfills the times recommended by the MTS. Analyzing the flow of women victims of RAT contributed to optimize the quality and efficiency of care.

Descriptors: Accidents; Traffic; Women; Patient Admission; Nursing; Triage.
\end{abstract}

\section{RESUMO}

Objetivo: analisar o fluxo do atendimento a mulheres vítimas de Acidentes de Transporte Terrestre (ATT). Método: estudo descritivo, com 782 mulheres vítimas de ATT, classificadas pelo Sistema de Triagem de Manchester (STM), entre 2015 a 2016. Analisou-se o perfil sociodemográfico e o tempo entre as etapas do atendimento, bem como o local de atendimento e desfecho. Resultados: das mulheres do estudo, $65,47 \%$ eram adultas jovens, $80,44 \%$ viviam sem companheiro(a) e $62,28 \%$ residiam em Belo Horizonte. Em relação ao tempo entre o registro e a classificação de risco, apresentou-se média de 7,7 minutos (DP:9,9). O fluxograma prevalente foi "Grande Traumatismo" (62,92\%). 53,07\% obteve nível de prioridade "Vermelho/Laranja" e o desfecho mais prevalente foi "Alta após consulta/medicação". Conclusão: o estudo evidencia que o hospital cumpre parcialmente os tempos preconizados pelo STM. Analisar o fluxo de mulheres vítimas de ATT contribuiu para otimizar a qualidade e eficiência da assistência.

Descritores: Acidentes de Trânsito; Mulheres; Admissão do Paciente; Enfermagem; Triagem.

\section{RESUMEN}

Objetivo: analizar el flujo de atención de mujeres víctimas de Accidentes de Transporte Terrestre (ATT). Método: estudio descriptivo, con 782 mujeres víctimas de ATT, clasificadas por el Sistema de Triaje de Manchester (STM), entre 2015 y 2016. Se analizó el perfil sociodemográfico y el tiempo entre las etapas de la atención, así como el local de atención y desenlace. Resultados: de las mujeres del estudio, el 65,47\% eran adultas jóvenes, el $80,44 \%$ vivía sin compañero (a) y el $62,28 \%$ residían en la ciudad de Belo Horizonte. En cuanto al tiempo entre el registro y la clasificación de riesgo, se presentó promedio de 7,7 minutos (DE: 9,9). El diagrama de flujo prevalente fue "Gran Traumatismo" (62,92\%). El 53,07\% obtuvo un nivel de prioridad "Rojo/Naranja" y el resultado más prevalente fue "Alta tras consulta/medicación". Conclusión: el estudio evidencia que el hospital cumple parcialmente los tiempos preconizados por el STM. El análisis del flujo de mujeres víctimas de ATT contribuyó a optimizar la calidad y eficiencia de la asistencia.

Descriptores: Accidentes de Tránsito; Mujeres; Admisión del Paciente; Enfermería; Triaje. 


\section{INTRODUCTION}

Road Traffic Accidents (RTA) represent a major global public health problem, being the ninth leading cause of death in the world. 1.25 million people die and 50 million suffer injuries every year ${ }^{(1)}$. Similarly, in Brazil, because of RTA, in 2016, about 35 thousand people died and approximately 180 thousand were admitted to the Brazilian Unified Health System (SUS - Sistema Único de Saúde). Of this total, 6 thousand deaths and 36 thousand hospitalizations were of female persons ${ }^{(2)}$.

In the middle of World War II, women gained a place in the labor market and assumed hierarchical positions previously occupied only by $\operatorname{men}^{(3)}$. Since then, the index of the economically active female population has been increasing and currently accounts for $44 \%$ of the Brazilian population ${ }^{(4)}$. In Brazil, the change in lifestyle resulting from the transformation of the role of women in society is a way of understanding the reason why, in 2016, transportation accidents, among external causes, represented the second cause of death in women $^{(2,5)}$. Between 1990 and 2015, there was a drop of the RTA rate by $32.8 \%$, in Brazil $^{(6)}$.

Such occurrences, due to RTA, are becoming commonplace in urgency and emergency services, directly involving women. In addition to generating expenses, these occurrences cover several health sectors, such as specialization, physical rehabilitation, psychology, and social work ${ }^{(7)}$.

In the recent literature, there are few Brazilian studies that analyze women's RTAs and contribute to strategic planning in relation to the theme of this research ${ }^{(1,3,8)}$. In addition, statistics show that the number of RTAs among women is relevant. This population group presents special care ${ }^{(5,7)}$.

Hospital care requires nurses to act based on the individuality and basic human needs of women victims of RTA ${ }^{(9)}$. There is a need to know the reality of health services, rethink and devise strategies for effective hospital care.

\section{OBJECTIVE}

This study aims to analyze the care flow for women victims of Road Traffic Accidents (RTA).

\section{METHODS}

\section{Ethical aspects}

This study was based on the national recommendations for the development of research with human beings and was approved by the Research Ethics Committee of the Universidade Federal de Minas Gerais. There was release from signing the Free and Informed Consent Form.

\section{Design, place of study and period}

This is a descriptive study carried out with women care at the Emergency Room of a public and teaching hospital in the city of Belo Horizonte - Minas Gerais, from January 2015 to December 2016. The hospital is a reference in urgency and clinical and surgical emergencies, traumatology, vascular surgery and Risk Classification (RC), with the use of the Manchester Triage System (MTS) since 2008.

\section{Population, inclusion criteria}

The initial population consisted of 31,829 women treated in the emergency room. Of these 728 , after data processing, they were 18 years of age or older, classified as RTA victims treated at the emergency room at the study site and classified by MTS at admission.

MTS is a clinical instrument used in emergency services to build the flow of users, ensuring medical attention according to the response time and the needs of the patient. Based on the main complaint, a specific flowchart is made up of discriminators by which the nurse analyzes the signs and symptoms, classifying the patient by color/ category: 1 - Red (Emergency), 2 - Orange (Very Urgent), 3- Yellow (Urgent), 4 - Green (Little urgent) and 5 - Blue (Not Urgent) and sets the maximum waiting time for the first medical care ${ }^{(10)}$.

The category V01-V89 was classified as RTA within the International Classification of Diseases-ICD10, from which the corresponding flowcharts and discriminators were selected.

\section{Study protocol}

Data collection was performed by means of the survey of the variables in the electronic medical records. The data was requested from the Information Technology sector of the setting institution that has two data storage software, one of which is to manage medical records and one to carry out RC, according to the MTS. With this information, the database of this study was created.

The women were followed from admission until their end of the service in the first aid. The study variables refer to age, marital status, city of residence, elements related to $\mathrm{RC}$, average time elapsed between the stages of care (registry, RC, medical care), care place after RC and care outcome.

The RC data followed the determinations of the MTS ${ }^{(9)}$. Flowcharts, determined according to the complaint (signs and symptoms) presented by the patients, besides the discriminators, were grouped according to their similarities. There was an analysis of the clinical priority level assigned by color, priority, and a maximum time for the first medical care. They were 1- Red/ emergency/maximum response time of 0 minutes; 2- Orange/ very urgent/maximum response time of 10 minutes; 3- Yellow/ urgent/maximum response time of 60 minutes; 4- Green/little urgent/maximum response time of 120 minutes; and 5- Blue/not urgent/maximum response time of 240 minutes (respectively) ${ }^{(10)}$.

The patients were divided into three age groups:young adults (18 to 40 years), adults (41 to 59 years) and elderly (60 years or above). Regarding marital status, they were classified as "living with a partner" and "living without a partner". In relation to the residence city, the population of this study was divided into three groups, the first group being composed of women living in Belo Horizonte; the second by those residing in the Metropolitan Region of Belo Horizonte; and a third group composed of women who lived in other cities.

\section{Analysis of results and statistics}

Stata software version 14.0 was used for the statistical treatment of the data. For the purpose of this study, schematic representations were constructed using MTS flowchart figures, which indicate the clinical priorities of the patients. The clinical priority 
classified as 1-Red (Emergency) was attached to 2-Orange (Very Urgent) due to the low number of data classified as "Red" $(n=1)$.

Three average service times were evaluated: time between the "Registry and RC"; "RC Duration" time; and time between "RC and First Medical Care", which is presented according to the priority level.

The care place of patients after RC included the categories: "Yellow rooms (medical and surgical clinic, neurology and vascular)", "Medical/surgical clinic emergency rooms", "Orthopedics Room” and "Suture Room". The outcome of the visits was categorized as "Discharge after consultation/medication", "Hospitalization", "Discharge with referral", "Transference to another hospital", "Withdrawal" and "Avoidance".

The population of this study was described. Estimates were presented in absolute and relative frequencies, with the respective Confidence Intervals $(95 \% \mathrm{Cl})$ of the proportions. For the numerical variables, after the symmetry was verified by the Shapiro-Wilk test, the data were presented by mean and Standard Deviation (SD).

\section{RESULTS}

The population of this study was composed of 782 women aged 18 to 94 years. The majority (65.47\%) were between 18 and 40 years old at the time of RTA, living without a partner (80.44\%) and living in Belo Horizonte (62.28\%) (Table 1).

The data referring to $\mathrm{RC}$ according to the MTS are presented in Table 2.

In relation to the flowcharts, it was observed that for the majority (62.92\%) of the women, the flowchart "Great Trauma" was followed, followed by "Falls" (12.15\%) and "Limbs Problems" 64\%) (Table 2).

The discriminators that allowed more than $88 \%$ determination of clinical priority were the combination of "Trauma Mechanism + Exposed Fracture + Direct Trauma + Cranioencephalic Trauma History (45.40\%)" and "Mild + Moderate + Pleuritic Pain (43.09\%)" (Table 2).

Regarding the color (determination of the priority level of care), it was found that the ones classified as 1- Red (Emergency) and 2-Orange (Very Urgent) corresponded to the highest proportion of visits (53.07\%) (Table 2 ).

Table 1 - Distribution of women victims of Road Traffic Accidents according to age, marital status, and city of residence, Belo Horizonte, Minas Gerais, Brazil, 2015-2016

\begin{tabular}{lcc}
\hline \multicolumn{1}{c}{ Variables } & $\mathbf{n ( \% )}$ & $\mathbf{9 5 \%} \mathbf{C l}$ \\
\hline Age & & \\
Young adults (18 to 40 years) & $512(65.47)$ & $62.06-68.73$ \\
$\quad \begin{array}{l}\text { Adult (41 to 59 years) } \\
\text { Elderly (60 years and over) }\end{array}$ & $182(23.27)$ & $20.44-26.37$ \\
Marital Status & & $9.21-13.67$ \\
$\quad$ Living with a partner & $153(19.56)$ & $16.97-22.55$ \\
$\quad$ Living with no partner & $629(80.44)$ & $77.44-83.02$ \\
City/residence place & & \\
Belo Horizonte & $487(62.28)$ & $58.81-65.61$ \\
$\quad$ Metropolitan region of Belo & $287(36.70)$ & $33.38-40.14$ \\
Horizonte & & \\
Other cities & $8(01.02)$ & $0.51-2.03$ \\
\hline
\end{tabular}

Notes: RTA = Road Traffic Accidents; 95\% Cl= 95\% Confidence Interval.
Table 2 - Risk Classification profile according to Manchester Triage System of women victims of Road Traffic Accidents, Belo Horizonte, Minas Gerais, Brazil, 2015-2016

\begin{tabular}{lc}
\hline \multicolumn{1}{c}{ Variables } & $\mathbf{n}(\%)$ \\
\hline Flowchart & \\
Great Trauma (major trauma) & $492(62.92)$ \\
Falls & $95(12.15)$ \\
Limbs Problems (extremities) & $91(11.64)$ \\
CET & $27(3.45)$ \\
Others & $77(9.84)$ \\
Discriminators & \\
Trauma Mechanism + Exposed Fracture + Direct & \\
Trauma + Cranioencephalic Trauma History & $355(45.40)$ \\
Mild + Moderate + Pleuritic pain & $337(43.09)$ \\
Severe pain & $66(8.44)$ \\
Unconsciousness History + Sudden Change + & $17(2.17)$ \\
Neurological Deficit & $2(0.26)$ \\
Inadequate Breathing + Acute Dyspnoea & $5(0.64)$ \\
Edema & \\
Priority level (color) & $415(53.07)$ \\
1- Emergency (Red) / 2- Very Urgent (Orange) & $325(41.56)$ \\
3- Urgent (Yellow) & $42(5.37)$ \\
4- Little Urgent (Green) & \\
\hline
\end{tabular}

Notes: $R T A=$ Road Traffic Accidents, CET = Cranioencephalic Trauma.

Three different service intervals were evaluated. The mean waiting time between the patients' registry and RC was 7.7 minutes (min) (SD: $9.9 \mathrm{~min})$. The mean RC duration was $2.4 \mathrm{~min}$ (SD: $1.4 \mathrm{~min}$ ) (data not shown). Mean intervals between RC and medical care

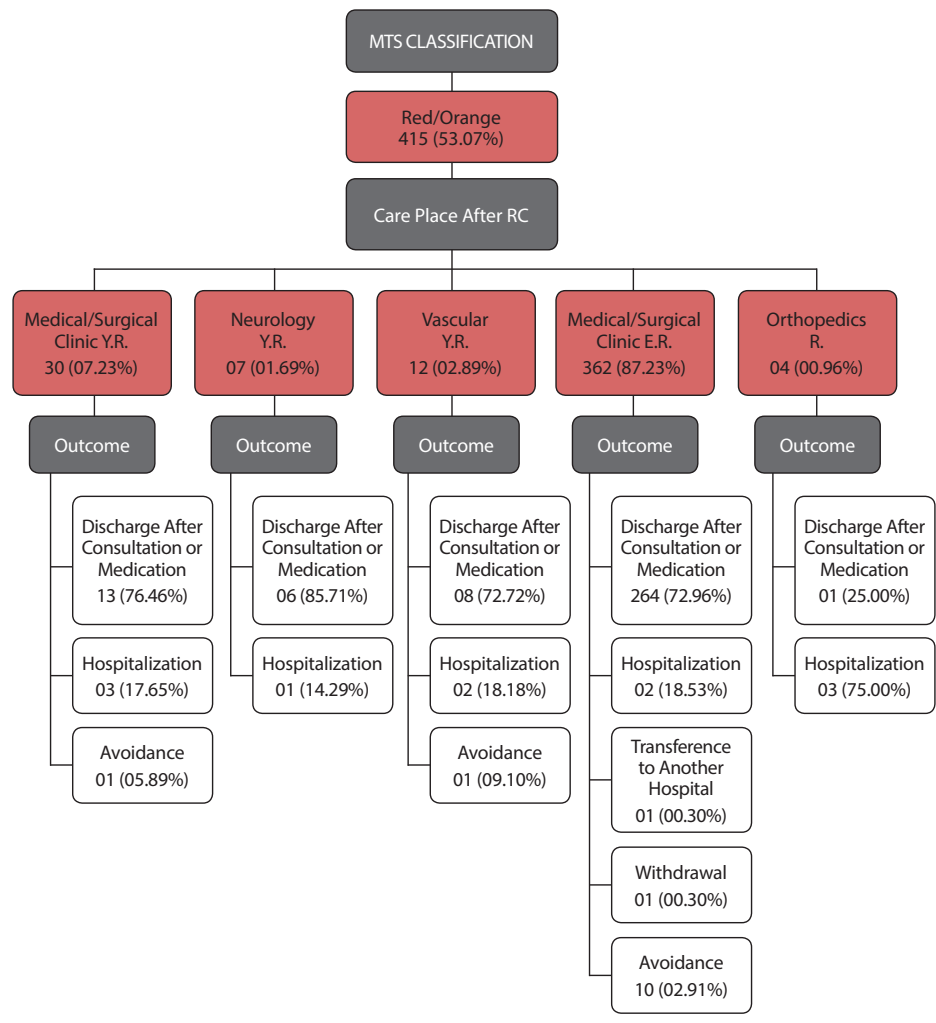

Notes: $R C=$ Risk Classification; Y.R. $=$ Yellow Room; E.R. = Emergency Room; $R .=$ Room

Figure 1 - A schematic analysis of the flow of care for women victims of Road Traffic Accidents and outcome of patients classified with priority levels 1- Red (Emergency) and 2- Orange (Very Urgent), Belo Horizonte, Minas Gerais, Brazil, 2015-2016 
were also evaluated according to the level of priority. As for the priority level 1 - Red (Emergency) and 2 - Orange (Very Urgent), the average time was $15.1 \mathrm{~min}$ (SD: $10.5 \mathrm{~min}$ ). Patients classified as 3 - Yellow (Urgent), average time was $59.1 \mathrm{~min}$ (SD: $63.2 \mathrm{~min}$ ). The ones classified as 4- Green (Little Urgent) presented average time of $153.4 \mathrm{~min}$ (SD: $138.5 \mathrm{~min}$ ) (data not shown).
The distribution of patient care sites after RC and their outcome are shown in Figures 1, 2, and 3. According to Figure 1, it was identified that the majority (87.23\%) of the women classified as "Red/ Orange" priority level, was referred to the "Medical/surgical clinic emergency rooms". Of these, $76.96 \%$ were discharged after consultation/medication, that is, they did not require hospitalization.

Figure 2 shows that the majority (65.54\%) of the women classified as a "Yellow" priority level were referred to the "Medical/surgical clinic yellow rooms". Of these, $90.86 \%$ were discharged after consultation/medication as an outcome.

In Figure 3, the majority of women classified as a "Green" priority level were referred predominantly to the "Medical/ Surgical Clinic Yellow Rooms" (40.47\%) and the "Orthopedics Room" (38.10\%).

\section{DISCUSSION}

It was observed in this study that the majority of women victims of RTA were between 18 and 40 years old (young adults) and did not live with a partner. Age data coincide with those of the Applied Economics Research Institute (IPEA - Instituto de Pesquisa Econômica Aplicada) in 2016, which points out that the highest number of victims of traffic accidents in Brazil (70\%) are young people aged between 15 and 49 years ${ }^{(3)}$. These results indicate that women in this age group and living without partners are more likely to suffer from RTA, since they are of economically active age and became

Figure 2-A schematic analysis of the flow of care for women victims of Road Traffic Accidents and outcome of patients classified with priority levels 3 - Yellow (Urgent), Belo Horizonte, Minas Gerais, Brazil, 2015-2016

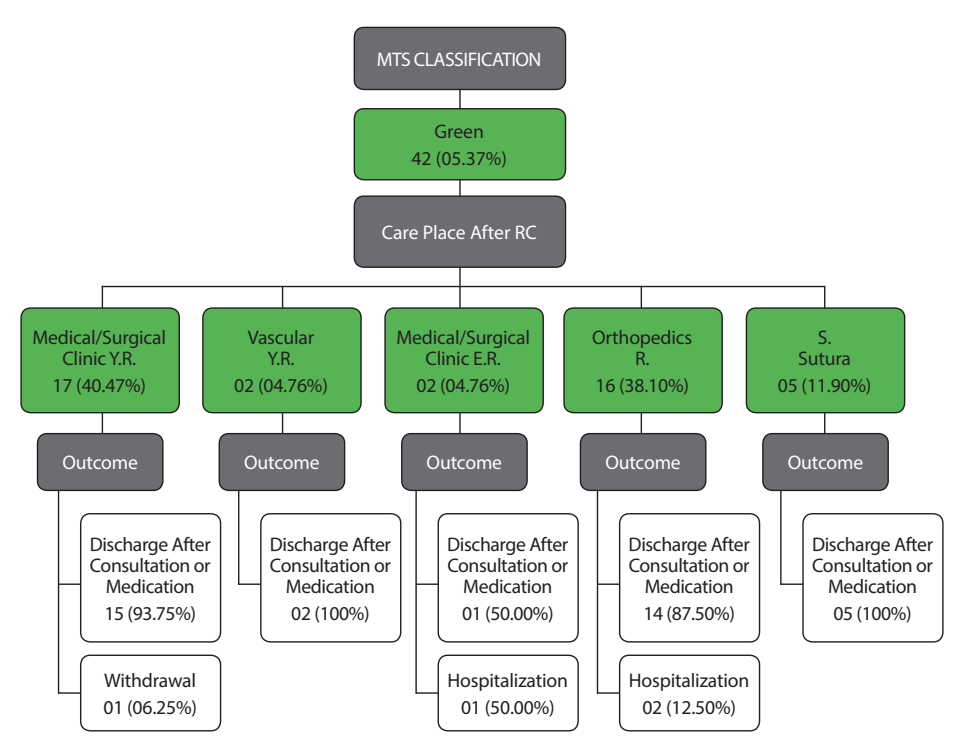

Notes: $R C=$ Risk Classification; Y.R. $=$ Yellow Room; E.R. = Emergency Room; $R .=$ Room.

Figure 3-A schematic analysis of the flow of care for women victims of Road Traffic Accidents and outcome of patients classified with priority levels 4- Green (Little Urgent), Belo Horizonte, Minas Gerais, Brazil, 2015-2016 financially independent after the conquest of positions previously occupied only by men ${ }^{(3,11)}$.

Regarding the city of residence of women victims of RTA, the majority resided in Belo Horizonte, where the institution studied is based. According to data from the Instituto Brasileiro de Geografia e Estatística (IBGE - Brazilian Institute of Geography and Statistics) in 2017, this is the most populous municipality in Minas Gerais State, with a large territorial area and diversified relief, where there is heavy traffic of land transport vehicles. These characteristics differ from other cities in the state, which, because of their size, facilitate "walking mobility", thus preventing women from using transport vehicles ${ }^{(12)}$.

The number of visits made to women residing in the Metropolitan Region of Belo Horizonte reflects the need to support these municipalities. This makes it possible to review the organization of the referral and referral system between these cities, since this system aims to improve overall patient care, not to overload the service $^{(13)}$. It is also noted that the institution complies with Ordinance 1,820 of August 13, 2009, which provides for the obligation of health services, to receive and care 
for people in situations of urgency and emergency, and to refer them to another service, if necessary ${ }^{(14)}$.

The main flowcharts accessed during the RC, in this study, were: "Great Trauma" followed by "Falls". The discriminators that led to more than $88 \%$ of the clinical priority determination were the junction of "Trauma Mechanism + Exposed Fracture + Direct Trauma + Cranioencephalic Trauma History" and "Mild + Moderate + Pleuritic pain". These data are consistent with a review study that stresses that the discriminators used for classification. When specific, such as those found in this study, are applied to particular cases (such as ejection of a vehicle, death of occupants, significant deformation of a vehicle and falls), tending to be related to the key characteristics of the traumas resulting from these case ${ }^{(15)}$. Thus, flowcharts correctly designated and guided by specific discriminators, allow the reliable classification of patients submitted to this system.

Regarding the classification of the priority level, approximately 95\% of the total were classified as "Red (Emergency)/Orange (Very Urgent)" and "Yellow (Urgent)". These values indicate that the emergency room of the study institution fulfills its reference role in urgency and emergency. The data show that the patients, who need more complex care, are referred to this service ${ }^{(16)}$. It is worth mentioning that trauma victims may have significant sequel reduction and even mortality, when the time elapsed between the accident and hospital care is the lowest possible ${ }^{(17)}$.

Regarding the analyzed time intervals, to our knowledge, only two Brazilian studies ${ }^{(10,18)}$ and one European ${ }^{(19)}$ study carried out such an evaluation. The present study found average time between recording and RC of 7.7 minutes. In a Brazilian study, the average time of 12 minutes was found. However, the maximum time recommended by the MTS is 10 minutes $^{(10,18)}$. Two other studies observed a median time of 6 minutes for the interval between recording and $\mathrm{RC}^{(19-20)}$. Regarding the $\mathrm{RC}$ duration, an average time of 2.4 min was found. National studies reported an average time of 2 minutes ${ }^{(18-19)}$. It is known that the MTS recommends that RC should not exceed 3 minutes ${ }^{(10)}$.

MTS is indicated to optimize waiting times for patients who need urgent and emergency care, and to ensure that they receive it properly ${ }^{(10)}$. Thus, these values show that the study institution has perfected its classification system, with professionals qualified to perform such functions. The nurse stands out as an important agent of this process. He performs RC through its abilities to evaluate the biological, social and psychological needs of the users, contributing to decrease the waiting time and prioritizing care according to the patient's clinical condition ${ }^{(21)}$.

Regarding the average time between RC and medical care, no literature was found that allows comparing this value in isolation, since it is related to the user's priority level. In this way, the analysis of this time interval was carried out next to the classification of each priority level (color). The "Red/Orange" and "Green" rankings exceeded the maximum time recommended by the MTS. In relation to the classification "Yellow", the average time remained within the proposed in the literature. These values can be justified on the basis of the great demand for care in highly complex health units, in which there is logistical difficulty to meet the high demand of patients admitted to the services ${ }^{(18)}$. Another condition that may interfere is the fact that the medical records of the most serious clients occur only after the stabilization of their health status.

According to the schematic analyzes of the flow of care for women victims of RTA in this study regarding the care place after $\mathrm{RC}$, the majority of the women, classified by MTS, were referred to the medical and surgical clinic rooms. This result corroborates with the bibliography found, in which it identified that more than half of the visits were performed by the medical-surgical clinics ${ }^{(19)}$. This is justified by the mechanism of trauma caused by RTA, with the conclusion that a more detailed investigation of the clinical condition of the patients should be applied. For this, there is a need for specific clinics $^{(22)}$.

As an outcome of the visits to women victims of RTA, the most prevalent was "Discharge after consultation/medication". Although the discharge after consultation or medication was the most prevalent outcome, it was observed that, at all priorities levels, the transfer to the hospitalization unit (hospitalization) also presented as an outcome. This information is consistent with the latest data from the Sistema de Vigilância de Violências e Acidentes (VIVA - Violence and Accidents Surveillance System) survey carried out in urgency and emergency services of 23 capitals and the Federal District. According to this survey, transportation accidents were one of the main reasons for hospital admissions, and $67 \%$ of the cases evolved to hospital discharge in 24 hours of care, followed by $23.1 \%$ of the cases that were referred for hospital admission ${ }^{(23)}$.

The number of care resulting from RTA is high. RTA generates high costs for the system, since it represents great economic and social impact, mainly, since it is predominant in young people and economically active. In 2015, RTAs generated an estimated global cost of $\$ 518$ billion $^{(1)}$. It is also estimated that 1 in 20 RTA victims will be permanently disabled. In addition to financial costs, RTA leads to physical and psychological sequels, directly interfering with women's work activities ${ }^{(24)}$.

In Brazil, initiatives have been taken to deal with the high death toll caused by RTA. The most emphatic initiative was the implementation of the Brazilian Traffic Code (Código de Trânsito Brasileiro) ${ }^{(25)}$ of 1998, which provided a significant reduction in the mortality rate by $\mathrm{RTA}$. Added to this initiative is Law 11.70522 called the Lei Seca (literally Portuguese for Dry Law), which entered into force in June 2008. It is about the association between alcoholic beverage and management, with an immediate impact on the changing behavior of the population ${ }^{(26)}$. Injuries and deaths surveillance and prevention actions caused by traffic, health promotion and culture of peace carried out by the Ministry of Health cannot be suppressed through Políticas Nacionais de Redução da Morbimortalidade por Acidentes e Violência (Brazilin Morbidity and Mortality by Accidents and Violence Reduction Policies) (GM (Gabinete do Ministro - Minister's Office)/MoH Ordinance 737, May 16, $2001^{(27)}$ and "Health Promotion" (Ordinance GM (Gabinete do Ministro Minister's Office)/MoH 687, March 30, 2006) ${ }^{(28)}$.

\section{Study limitations}

Although the study was from a cohort, its retrospective design led to some loss of information (patients not classified by MTS).It 
Analysis of triage and care for women victims of road accidents Matozinhos FP, Silverio IR, Boaventura JG, Oliveira TM, Silva TPR, Corrêa AR.

should be noted that these were checked through other forms of data. However, the active search of the patients was not possible. Another limitation is the fact that a population with proven representativeness of the Brazilian population was not used, which may restrict the validity of the results. Although the study conducted is in the first aid of a large hospital, the results refer to the local services. Therefore, the possibility of conclusive analysis is restricted only to the population served in the referred hospital.

\section{Contribution to the fields oh Nursing and Health}

This is one of the few recent studies analyzing the outflow and outcome of women victims of RTA from a large public hospital in a developing country. Certainly, it represents progress towards a better understanding of the national profile of women in this specific service. Such knowledge can be very useful for managers and health professionals, who work in urgency and emergency units, to know the results of their professional practices. This allows the identification of possible improvements in care and RC. Therefore, this work can help in the qualification and adequacy of human and material resources, as well as in the elaboration of a Situational Diagnosis of the emergency room care of large public hospitals of women victims of RTA.

\section{CONCLUSION}

The results showed that the women victims of RTA were mostly young adults lived without a partner and lived in the city of Belo Horizonte. They also show that the time between registry, RC, and classification duration are within the one recommended by MTS. For the "Very Urgent" and "Little Urgent" priority level, the hospital requires more time than recommended by MTS.

In relation to the most accessed flowchart, it was observed the "Great Trauma" with priority level "Red/Orange". Regardless of the priority level assigned to patients, the most prevalent outcome was "Discharge after consultation/medication".

The analysis of the outflow and outcome of women victims of RTA from a large public hospital contributes to optimize time management, thus increasing the quality and efficiency of care.

\section{FUNDING}

This project was funded by the Pro-Rectory of Research of the Universidade Federal de Minas Gerais - PRPQ/UFMG under number 23853/2016, and by the Research Support Foundation of Minas Gerais State - FAPEMIG (Fundação de Amparo à Pesquisa do Estado de Minas Gerais) under number APQ-03137-17.

\section{REFERENCES}

1. World Health Organization-WHO. Global status report on road safety 2015. Switzerland: WHO [Internet]. 2015[cited 2018 Jan 23]. Available from: http://www.who.int/violence_injury_prevention/road_safety_status/2015/en/

2. Ministério da Saúde (BR). DATASUS: Departamento de Informática do SUS: Portal da Saúde. [Internet]. 2018 [cited 2018 Jan 23]. Available from: http://www2.datasus.gov.br/DATASUS/index.php?area=02

3. Barros JYF, Santos KS. A inserção do gênero feminino na condução de motocicleta no município de Maceió/AL e a relação com a acidentalidade. Bahia:V Seminário Internacional Enlaçando Sexualidades, 10 anos[Internet]. Anais eletrônicos. 2017[cited 2018 Jan 24] Available from: http://www.editorarealize.com.br/revistas/enlacando/trabalhos/TRABALHO_EV072_MD4_SA32_ID1123_17072017142410.pdf

4. Ministério da Saúde (BR). Políticas de proteção e inclusão de gênero. Ministério da Fazenda. Secretaria de Previdência. Brasília [Internet]. 2017[cited 2018 Jan 24]. Available from: http://www.previdencia.gov.br/wp-content/uploads/2017/12/Apresenta\%C3\%A7\%C3\%A 3o-sobre-Equidade-de-g\%C3\%AAnero-Avelina.pdf

5. Davantel PP, Pelloso SM, Carvalho MDB, Oliveira NLB. A mulher e o acidente de trânsito: caracterização do evento em Maringá, Paraná. Rev Bras Epidemiol[Internet]. 2009[cited 2018 Jan 24];12(3):55-67. doi: http://dx.doi.org/10.1590/S1415-790X2009000300006

6. Ladeira RM, Malta DC, Morais-Neto OL, Montenegro MMS, Soares-Filho AM, Vasconcelos CH, et al . Acidentes de transporte terrestre: estudo Carga Global de Doenças, Brasil e unidades federadas, 1990 e 2015. Rev Bras Epidemiol [Internet]. 2017[cited 2018 Oct 26];20(Suppl-1):157-70. doi: $10.1590 / 1980-5497201700050013$

7. Vieira RM, Queiroz IFR. Karolline GSV, Zélia MAM, Sandra MCF, Maria SCL. Mortalidade segundo causas externas entre mulheres em idade fértil, no município de Sobral, Ceará. Sanare[Internet]. 2014[cited 2018 Jan 25];13(2):70-7. Available from: https://sanare.emnuvens.com.br/sanare/ article/view/576

8. Morais-Neto OL, Montenegro MMS, Monteiro RA, Siqueira-Júnior JB, Silva MMA, Lima CM, et al . Mortalidade por acidentes de transporte terrestre no Brasil na última década: tendência e aglomerados de risco. Ciênc Saúde Coletiva [Internet]. 2012 [cited 2018 Oct 26]; 17(9):2223-36. doi: 10.1590/S1413-81232012000900002

9. Lins TH, Lima AXBC. Nursing diagnoses and interventions in trauma victims during prehospital care using the ICNP®. Rev Eletr Enf[Internet]. 2013[cited 2018 Jan 26];15(1):34-43. Available from: http://dx.doi.org/10.5216/ree.v15i1.16503

10. Mackway-Jones K, Marsden J, Windle J. Versão brasileira de Rausch MCP, Junior WC. Carvalho CA, Nascimento GFL, Rocha PTB, (Colabs.). Sistema Manchester de Classificação de Risco - 2a Edição. 206 p. Belo Horizonte: Folium; 2017.

11. Carvalho CHR. Mortes por acidentes de transporte terrestre no Brasil: análise dos sistemas de informação do Ministério da Saúde. Instituto de Pesquisa Econômica Aplicada - IPEA. Brasília: Rio de Janeiro, 2016. 50 p.

12. Instituto Brasileiro de Geografia e Estatística - IBGE. Cidades [Internet]. 2010[cited 2018 Jun 10]. Available from: https://cidades.ibge.gov.br/ brasil/mg/belo-horizonte/panorama 
Analysis of triage and care for women victims of road accidents Matozinhos FP, Silverio IR, Boaventura JG, Oliveira TM, Silva TPR, Corrêa AR.

13. Alves MLF, Guedes HM, Martins JCA, Chianca TCM. Rede de referência e contra referência para o atendimento de urgências em um município do interior de Minas Gerais - Brasil. Rev Med Minas Gerais[Internet]. 2015[cited 2018 Jun 09];25(4):469-75. Available from: http:// www.rmmg.org/artigo/detalhes/1859

14. Ministério da Saúde (BR). Portaria № 1.820, de 13 de agosto de 2009. Dispõe sobre direitos e deveres dos usuários da saúde. Diário Oficial da União: Brasília [Internet]. 2009[cited 2018 Jun 10]; Seção 1, p. 80. Available from: http://conselho.saude.gov.br/ultimas_noticias/2009/01_set_carta.pdf

15. Coutinho AAP, Cecílio LCO, Mota JACM. Classificação de risco em serviços de emergência: uma discussão da literatura sobre o Sistema de Triagem de Manchester. Rev Med Minas Gerais [Internet]. 2012[cited 2018 Jun 10];22(2):188-98. Available from: http://www.rmmg.org/ artigo/detalhes/101

16. Araújo JHV, Chaves GMM, Barbosa JV, Nunes CMP. Compreensão dos usuários do SUS sobre a classificação de risco na rede de urgência e emergência por meio de um programa de educação tutorial. Rev Med Minas Gerais[Internet]. 2017[cited 2018 Jun 10];26:e-1823. Available from: http://dx.doi.org/10.5935/2238-3182.20160123

17. Carvalho ICCM, Saraiva IS. Perfil das vítimas de trauma atendidas pelo serviço de atendimento móvel de urgência. Rev Interdisc[Internet]. 2015[cited 2018 Jun 23];8(1):137-48. Available from: https://revistainterdisciplinar.uninovafapi.edu.br/index.php/revinter/article/ view/392

18. Chianca TCM, Costa RM, Vidigal MV, Silva LCR, Diniz GA, Araújo JHV, et al. Tempos de espera para atendimento usando Sistema de Triagem de Manchester em um hospital de urgência. Rev Min Enferm[Internet]. 2016[cited 2018 Jun 10];20:e988. Available from: http://www.dx.doi. org/10.5935/1415-2762.20160058

19. Storm-Verslot MN, Vermeulen H, Van Lammeren N, Luitse JSK, Goslings JC. Influence of the Manchester Triage System on waiting time, treatment time, lenght of stay and patient satisfaction; a before and after study. Emerg Med J[Internet]. 2014[cited 2018 Jun 10];31(1):13-8. Available from: http://emj.bmj.com/content/31/1/13

20. Anziliero F, Soler BED, Silva BA, Tanccini T, Beghetto MG. Sistema Manchester: tempo empregado na classificação de risco e prioridade para atendimento em uma emergência. Rev Gaúcha Enferm [Internet]. 2016[cited 2018 Jun 10];37(4):e64753. Available from: https://www.lume. ufrgs.br/bitstream/handle/10183/163226/001017179.pdf?sequence=1

21. Lima S, Paula AS. Atuação do enfermeiro na aplicação do protocolo de Manchester em unidades de urgência e emergência. Rev Científ Univiçosa[Internet]. 2016[cited 2018 Jun 10];8(1):137-42. Available from: https://academico.univicosa.com.br/revista/index.php/ RevistaSimpac/article/viewFile/629/776

22. Baldoino LS, Oliveira MHR, Baldoino LS, Virgineo MS. Perfil das Vítimas de Acidentes de Trânsito Atendidas no Hospital Público de Floriano -PI. Rev Interdisc [Internet]. 2018[cited 2018 Jun 14];11(1):41-50. Available from: https://revistainterdisciplinar.uninovafapi.edu.br/index. $\mathrm{php} / \mathrm{revinter/article/view/1256}$

23. Ministério da Saúde (BR). Secretaria de Vigilância em Saúde. Departamento de Vigilância de Doenças e Agravos Não Transmissíveis e Promoção da Saúde. Viva: Vigilância de Violências e Acidentes, 2009, 2010 e 2011. Brasília: Ministério da Saúde[Internet]. 2013 [cited 2018 Jun 14]. Available from: http://bvsms.saude.gov.br/bvs/publicacoes/sistema_vigilancia_violencia_acidentes.pdf

24. Andrade SSCA, Jorge MHPM. Internações hospitalares por lesões decorrentes de acidente de transporte terrestre no Brasil, 2013: permanência e gastos. Epidemiol Serv Saúde[Internet]. 2017[cited 2018 Jun 14];26(01). Available from: https://doi.org/10.5123/ S1679-49742017000100004

25. Ministério dos Transportes(BR). Lei 9.503, de 23 de setembro de 1997. Código de Trânsito Brasileiro. Diário Oficial da União 1997, 24 setembro.

26. Ministério dos Transportes(BR). Lei 11.705, de 19 de junho de 2008. Altera a Lei no 9.503, de 23 de setembro de 1997, que 'institui o Código de Trânsito Brasileiro', e a Lei no 9.294, de 15 de julho de 1996, que dispõe sobre as restrições ao uso e à propaganda de produtos fumígeros, bebidas alcoólicas, medicamentos, terapias e defensivos agrícolas, nos termos do $\S 40$ do art. 220 da Constituição Federal, para inibir o consumo de bebida alcoólica por condutor de veículo automotor, e dá outras providências. Diário Oficial da União $2008 ; 20$ jun.

27. Ministério da Saúde (BR). Portaria GM/MS n 737, de 16/05/2001 - publicada no DOU no 96, Seção 1E de 18/05/2011, que institui a Política Nacional de Redução da Morbimortalidade por Acidentes e Violências. 2a Edição. Brasília (DF): MS; 2005. (Série E - Legislação de Saúde)

28. Ministério da Saúde (BR). Portaria GM/MS no 687, de 30/03/2006, que institui a Política Nacional de Promoção da Saúde. Brasília (DF): MS; 2006. (Série Pactos pela Saúde 2006 - Volume 07. Série B - Textos Básicos de Saúde) 